The Enemy of 'Ummah: Belief in Jewish conspiracy theories indirectly affected vaccination decisions

\author{
Rizqy Amelia Zein ${ }^{1}$ \\ Maghfira Fahmi Arinda ${ }^{1}$ \\ Audi Ahmad Rikardi ${ }^{1,2}$ \\ Ilham Akhsanu Ridlo ${ }^{3}$
}

Vania Ardelia ${ }^{1}$

${ }^{1}$ Department of Psychology, Universitas Airlangga

${ }^{2}$ Faculty of Psychology, Universitas Gadjah Mada

${ }^{3}$ Department of Health Policy and Administration, Universitas Airlangga

$* *$ This manuscript has not been peer-reviewed $* *$

Correspondence:

Rizqy Amelia Zein, Department of Personality and Social Psychology, Faculty of

Psychology Universitas Airlangga, Kampus B Unair, Jalan Airlangga 4-6, Surabaya, East Java, Indonesia 60286, email: amelia.zein@psikologi.unair.ac.id

Note: Audi Ahmad Rikardi and Maghfira Fahmi Arinda made an equal contribution to this manuscript. 


\begin{abstract}
In our three pre-registered studies, we aimed to unravel the root cause and societal implications of belief in Jewish conspiracy theories among Indonesian Muslims. Our findings in Study $1(N=385)$ confirmed our predictions that symbolic threat and collective narcissism were strongly related to belief in Jewish conspiracy and mediated the association between religious zeal and Jewish conspiracy beliefs. In Study $2(N=370)$, we found that Jewish conspiracy beliefs indirectly predicted vaccination refusal and delay through vaccination conspiracy beliefs, and observed no evidence to confirm the moderating role of religiosity in reinforcing vaccination conspiracy beliefs. In Study $3(N=396)$, we replicated our findings in Study 2 that belief in Jewish conspiracy theories was strongly related to vaccination conspiracy belief. Also, participants who blamed the Jews for the coronavirus pandemic were inclined to refuse a coronavirus vaccination when it is available. We argue that religiosity might not be directly related to conspiratorial thinking but, instead, activates a sense of outgroup threats among religious individuals making them more likely to endorse Jewish conspiracy theories. Despite the assumption that Jewish conspiracy theories are somehow benign, our findings dispute this premise.
\end{abstract}

Keywords: Jewish conspiracy beliefs, Indonesian Muslims, religiosity, outgroup threat, vaccination. 


\section{The Enemy of 'Ummah: Jewish conspiracy belief indirectly affected vaccination decisions}

In 1986, a Muslim cleric from Sumbawa, Indonesia complained to a researcher from the Indonesian Institute of Science (Lembaga Ilmu Pengetahuan Indonesia-LIPI) that his congregation was no longer interested in learning to recite the Qur'an independently due to the sudden popularity of the cassette. The new technology, in his opinion, endangered the 'ummah and suspected that Jews and Zionists were somehow behind the creation of this technology with the aim to abolish Muslims' values (van Bruinessen, 1994). Wild speculations about Jews and vaccinations were also causing serious public health concerns in 2019-resulting in low Measles-Rubella (MR) vaccination coverage in several areas in Indonesia, including Aceh (11.32\%), Riau (41.63\%), and West Sumatera (44.49\%) as the bottom three provinces (Sitohang, 2019). Despite the Islamic laws undoubtedly allowing vaccination (Mulia, 2018), a number of people continue defending their choice to reject vaccination-citing religious incompatibility as their main reason. Some people even justify this rationale by raising the senseless suspicion that vaccination is a part of the Jews' hidden agenda to taint the purity of Muslim children (Riyanto, 2018).

In recent days during the global coronavirus outbreak, a rampant spread of misinformation has deceived people into thinking that the Jews are the mastermind behind the creation of the virus. When the Islamic leaders announced a fatwa (edict) — urging their followers to observe daily prayers at home and to avoid congregation (Burhani, 2020), people became convinced that the virus was deliberately made by the Jews to alienate Muslims from their places of worship. The strength of Jewish conspiracy theories remains staggering, even after 
Muhammadiyah, one of the largest Islamic organisations in Indonesia, made a public call to stop circulating such nonsensical rumours (Saputra, 2020).

Jewish conspiracy theories are widespread in Southeast Asia, especially in Indonesia and Malaysia (Ainslie, 2019; Reid, 2010), and in others regions that are Muslim-majority, such as the Middle East and North Africa (Nyhan \& Zeitzoff, 2018), although it is difficult to comprehend why Indonesian Muslims often point their fingers to the Jews - a minuscule religious group barely existent in the archipelago (Franke, 2013). From a historical standpoint, there is some speculation about the origins of such wishful thinking. Van Bruinessen (1994) argued it was firstly introduced by clerics who spent their religious training in the Middle East, where such rhetoric is ubiquitous and politically powerful. Reid (2010) suspected that the rhetoric was very likely introduced de novo and might work as "a safe surrogate" for the resentment felt towards the Indonesian Chinese (Siegel, 2000). One might also suspect that Jewish stereotypes are derived from certain interpretations of the Qur'an, yet Islamic scholars carefully translated representations of Judaism and Jews in scripture are ambiguous rather than despicably negative - also emphasising that Jews are not all alike (Ali, 2010). Solidarity with Palestinian Muslims might only tell us a little part of the story since Indonesian Muslims liken Jews to liberalism, secularism, globalisation, and virtually all modern-ills that assail Islamic values (Siegel, 2000; van Bruinessen, 1994).

Unlike in other countries where anti-Jew rhetoric is also popular, such as Poland where the conspiracy theories related to Jews are particularly profound among the right-wing extremists (Bilewicz, Michał \& Krzeminski, 2010; Cichocka et al., 2015; Golec de Zavala \& Cichocka, 2012), Jewish conspiracy theory in Indonesia and neighbouring Malaysia is public, widespread, 
and worse, perpetuated by public figures, such as politicians, clerics, and celebrities (Reid, 2010; Swami, 2012; van Bruinessen, 2002). Although historians have found compelling data that the theory has been circulating for centuries, anti-Semitic rhetoric was greatly exacerbated during the New Order regime (Siegel, 2000). A contrived document-The Protocols of the Elders of Zion which contains allegations of a Jewish despicable conspiracy to destroy Islamic values, fueled the conspiracy belief about Jews and was deliberately circulated and endorsed by a number of military circles during the New Order regime (van Bruinessen, 2002). The New Order dictator, General Soeharto, notoriously raised an allegation that his downfall during the Asian financial crisis in 1998, was a result of Jewish conspiracy (Hadler, 2004).

The anti-Jewish rhetoric, albeit intense, can seem harmless because it is rarely channelled into discriminatory acts or violence, due to the lack of any Jewish community presence in the region (Ainslie, 2019). The dearth of evidence demonstrating the societal impact of Jewish conspiracy belief in Southeast Asia perpetuates this assumption. What needs to be also considered is the weight of sheer evidence from previous research demonstrating how conspiracy belief acts as an anti-science narrative and that could lead to real danger in our daily lives (Douglas et al., 2019), such as raising doubt about vaccination (Jolley \& Douglas, 2014), enticing prejudice towards minority groups (Imhoff \& Lamberty, 2017; Jolley et al., 2019), reducing intention to adopt sustainable behaviours (Lewandowsky et al., 2013), decreasing political engagement (Jolley et al., 2018), and further, justifying violence (Jolley \& Paterson, 2020). Additionally, prior research provides evidence that belief in Jewish conspiracies was, specifically, closely associated with generalised anti-Jewish and anti-Western attitudes (Nyhan \& Zeitzoff, 2018), while negative stereotypes about these groups were also related to belief in 
conspiracy theories about terrorism (Mashuri \& Zaduqisti, 2015) and could potentially lead to aggressive inclination towards both groups (Mashuri \& Zaduqisti, 2019).

Much past research has been dedicated to investigating personal factors behind conspiratorial ideation, such as a lack of analytical thinking (Swami et al., 2014), illusory correlations (Vitriol \& Marsh, 2018), right-wing authoritarianism and social dominance orientation (Swami, 2012), or a lack of control (Kofta et al., 2020). Nevertheless, to investigate the role of belief in Jewish conspiracy theories, the intergroup context deserves greater attention since Muslims in Southeast Asia perceive Jews mostly as an ideological scapegoat, rather than seeing them as a real threat (Reid, 2010; van Bruinessen, 2002). Conspiracy theory is also collective in nature - stemming from the motivation to maintain an ingroup's positive image, especially when it is deeply embedded in their social identity and perfectly aligned with the group's goals (Krekó, 2015).

Conspiracy theories are particularly omnipresent in a time of crisis (van Prooijen \& Douglas, 2017) or when the ingroup's image is severely or situationally threatened. In this case, group members who uphold the conspiracy belief tendency are in search of outgroups that can be blamed for their misfortunes or inferior position; this leads to a defensive identification within the group, often conceptualised as collective narcissism (Cichocka et al., 2015). Collective narcissists tend to see their groups as an extension of their own self-worth and thus constantly seek external validation of both their individual greatness and the eminence of their ingroup - reflecting the presence of unstable collective self-esteem and an inflated image of the ingroup's positivity (Cichocka, 2016; Golec de Zavala et al., 2009). They are overly sensitive to in-group insult and tend to retaliate against any attack on their ingroup's image with both direct 
and indirect hostility (Golec de Zavala et al., 2016). Studies in the UK (Golec de Zavala et al., 2017) and in Poland (Cichocka et al., 2016; Marchlewska et al., 2019) provide strong evidence of the relationship between collective narcissism and having a conspiracy mentality. A longitudinal study in the US also showed that collective narcissism was closely related to the growth of the conspiracy mentality over the course of the 2016 US Presidential election (Golec de Zavala \& Federico, 2018)

Although previous research has linked conspiracy mentality with religiosity-like constructs, such as paranormal belief (Darwin et al., 2011), and aligned conspiracy belief with quasi-religiousness (Franks et al., 2013), evidence to connect the dots between religiosity and conspiracy belief remains scarce. Meanwhile, conspiracy theories quite often plague religious communities (Marchlewska et al., 2019; Mashuri \& Zaduqisti, 2015). Prior research has revealed evidence of a possible link between religious belief, but not religious identification, and conspiracy belief (Jasinskaja-Lahti \& Jetten, 2019). We, nonetheless, need to fill an important gap remaining in our knowledge — why do religious individuals who believe in conspiracy theories not change their opinion after being exposed to solid counter-arguments from religious authorities?

\section{Overview of current studies}

In our three pre-registered studies, we sought to answer the following questions; (1) Do religious individuals tend to endorse conspiracy theories? (2) Does belief in Jewish conspiracy theories lead to real consequences, such as vaccination decisions? and (3) Under what circumstances do Indonesian Muslims associate Jewish conspiracies with vaccine conspiracies? 
Our first study aimed to unravel the first question as we suspected religiously zealous individual would be inclined to endorse Jewish conspiracy belief and since Muslims primarily believe Jews are a threat to the Islamic worldviews, the effect would also be mediated by symbolic threat (Stephan \& Stephan, 2000) and collective narcissism in parallel (Golec de Zavala, 2011).

Our second study intended to test our prediction that those who believe in Jewish conspiracy theories would fall into the trap of thinking that vaccines are a product of a malevolent conspiracy, especially those who declared religiosity plays an important role in their lives - this is because previous studies mention that religious incompatibility was a profound motivation for vaccination rejection, especially in Asia (Dubé, Gagnon, et al., 2014; Larson et al., 2016). We also expected that vaccine conspiracy belief would be a strong predictor of vaccine refusal and delay (Dubé, Vivion, et al., 2014; Jolley \& Douglas, 2014). At last, we wanted to lay out the conditions that allowed Jewish conspiracy belief to be transformed into vaccine conspiracy belief in Study 3. We suspected that when individuals' social identity is under attack and when religious authorities publicly scorn vaccination, one would be more likely to uphold vaccine conspiracy beliefs. Since societal upheavals, such as the coronavirus pandemic, are a breeding ground for derogatory views on "the common enemy" and conspiracy theories, we were also interested in finding out how blaming certain social groups, including Jews, for the coronavirus pandemic would affect coronavirus vaccination intention.

Our studies offer insight into the current body of knowledge by uniquely putting Muslims in the picture as a politically and socially dominant group, which differs from existing research portraying Muslims as a stereotyped group that signifies cultural threats (Swami et al., 2018) or as deprived religious minorities (van Prooijen et al., 2018). Apart from this, a global survey 
reported that young Indonesians believed that religiosity is a focal point of their happiness (Heriyanto, 2018), which diverged from the global trend. Our studies, therefore, propose an insightful contribution to the inquiry about the nexus between conspiracy mentality and religiosity, particularly in a religious community, while similar research has mainly been conducted in relatively secular communities (Jasinskaja-Lahti \& Jetten, 2019; Marchlewska et al., 2019).

\section{Disclosures}

Our materials, raw data, codebooks, and codes of all studies are available on Open Science Framework (OSF; https://osf.io/2gdwn/?view only=4e2f5f3276674b788f98afc815b2f076).

Preregistration of Study 1, Study 2, and Study 3 are available at https://osf.io/uabxt/?view only=2edc223fe4314f038eacb7042e09ebd9; https://osf.io/23rvt/?view only=0baf2faf2c39443cbc54055c059319b7; and https://osf.io/7w5nf/?view_only=653ffe759f5546cdaac0a6e85e784b0f respectively. Some of our decisions might have slightly deviated from the original plan, and we detailed those deviations in the supplementary materials.

\section{Study 1}

This study aimed to test our first prediction that a religiously zealous participant would be more likely to endorse Jewish conspiracy theories through parallel mediating factors (symbolic threat and collective narcissism). We also expected that symbolic threat would yield a direct 
effect on collective narcissism since it commonly emerges as a defensive strategy to cope with outgroup threats (Cichocka, 2016; Golec de Zavala et al., 2009).

\section{Method}

\section{Participants and Procedure}

Prior to data collection, we planned our sample size using a Monte Carlo simulation (Beaujean, 2014) using the simsem package in R (Pornprasertmanit et al., 2020; R Core Team, 2019). In order to detect prespecified small-to-medium correlations with $90 \%$ statistical power, we needed to recruit at least 328 participants. At the end of data collection, we had recruited 385 (76.3\% female) Indonesian Muslims by circulating invitations over several social media and instant messaging platforms. Participants' ages 21.57 years on average $(S D=5.66)$ and ranged from 18 to 53 years.

After giving their consent to participate, we measured participants' belief in a Jewish conspiracy, using the translated version of the Belief in Jewish Conspiracy scale (Swami, 2012) indicating their opinion ( $1=$ strongly disagree, $7=$ strongly agree $)$ in response to 12 statements. Items included, "Jews are attempting to establish a secret world government", "the Holocaust is a myth fabricated to serve Jewish interest", and "Jews are responsible for the social and moral ills in this country". We estimated its reliability using bootstrapped ordinal $\omega$ total $\left(\omega_{t}\right)$ (Dunn et al., 2014) and estimated its 95\% confidence intervals using a bias-corrected and accelerated (BCa) bootstrap (Kelley, 2018; Kelley \& Pornprasertmanit, 2016) with 1000 iterations, yielding a good reliability coefficient $\left(\omega_{t}=.912,95 \% \mathrm{CI}=[.897, .928]\right)$. 
We also measured participants' collective narcissism by asking them to complete the translated version of the nine-item Collective Narcissism scale (Golec de Zavala et al., 2009). Participants were asked to indicate their support ( $1=$ strongly disagree, $7=$ strongly agree $)$ of statements such as, "If Muslims were the majority religious community in the world, then the world would be a better place" and "Not everyone understands the virtues of being a Muslim". We estimated its reliability and yielded an acceptable reliability coefficient $\left(\omega_{t}=.821,95 \%\right.$ $\mathrm{CI}=[.790, .848])$.

Subsequently, participants were required to complete an eight-item Symbolic Threat scale (Stephan \& Stephan, 2000, 2017) by indicating their agreement (1=strongly disagree, $7=$ strongly agree) with items such as, “Jews destroy the Muslims’ faith by spreading liberalism and secularism" and "All individuals who claim to be Muslim should feel sad and offended when Jews attack Palestinians". A reliability analysis yielded a good reliability coefficient $\left(\omega_{t}=.864\right.$, $95 \% \mathrm{CI}=[.838, .883])$.

Finally, we measured participants' religious zeal by using the translated version of the Religious Zeal scale (McGregor et al., 2013). Participants indicated their opinion (1=completely different from my views, 5=completely fits my values) on items, such as "My religious teachings are based on absolute truths" and "I justify acts of violence, both verbal and physical if it has to be done to defend my beliefs". Reliability analysis showed a good reliability coefficient $\left(\omega_{t}=.864,95 \% \mathrm{CI}=[.838, .883]\right)$

\section{Results and Discussion}

To test our hypothesis, we performed full structural equation modelling, treating all scale items as ordinal and all variables of interest as latent variables. To estimate model parameters, we 
used the diagonally weighted least squares (DWLS) estimator, which is more accurate in yielding factor loading estimates in a model with ordinal variables ( $\mathrm{Li}, 2016)$. We conducted our analysis with the help of the lavaan package in R (Yves, 2012) (see Table 1 for the descriptive statistics).

Table 1.

Mean, Standard Deviations of Variables, and Zero-Order Correlations $(N=385)$

\begin{tabular}{llllll}
\hline \multicolumn{1}{c}{ Measure } & $\boldsymbol{M}(\boldsymbol{S D})$ & $\mathbf{1}$ & $\mathbf{2}$ & $\mathbf{3}$ & $\mathbf{4}$ \\
\hline 1. Belief in Jewish & $4.11(1.14)$ & - & & \\
Conspiracy & & & & \\
2. Symbolic Threat & $3.68(1.19)$ & .67 & - & \\
3. Collective Narcissism & $4.29(0.98)$ & .58 & .64 & - \\
4. Religious Zeal & $3.85(0.67)$ & .46 & .58 & .70 & - \\
\hline
\end{tabular}

Note. All correlations are significant at $p<.001$ level.

Factor loadings in the measurement model were all significant, $p<.001$, and in general, satisfactory_ranging from moderate-to-large loadings (0.309-1.953). After assessing absolute and incremental fit indices, we concluded that the model was overall a good fit. As shown in Figure 1, religious zeal was not significantly associated with belief in Jewish conspiracies $(B=-0.088,95 \% \mathrm{CI}=[-0.208,0.008], S E=0.056, p=.116)$, the loading was too small to be deemed meaningful and zero was included in its confidence interval. Religiously zealous participants were more likely to perceive Jews as a symbolic threat $(B=0.682,95 \% \mathrm{CI}=[0.584,0.795]$, $S E=0.054, p<.001)$ and tended to hold an unrealistic belief about the Muslim's greatness $(B=0.506,95 \% \mathrm{CI}=[0.388,0.617], S E=0.059, p<.001)$, while both symbolic threat $(B=0.344$, 
$S E=0.061,95 \% \mathrm{CI}=[0.224,0.445], p<.001)$ and collective narcissism $(B=0.242,95 \% \mathrm{CI}=[0.095$, 0.423], $S E=0.085, p=.004)$ significantly predicted belief in Jewish conspiracy. Also, participants who perceived Jews as a symbolic threat would be more likely to have higher collective narcissism $(B=0.288,95 \% \mathrm{CI}=[0.211,0.385], S E=0.045, p<.001)$. We also estimated indirect effects of religious zeal through collective narcissism (standardised IE $=0.122,95 \% \mathrm{CI}=[0.045$, $0.233], S E=0.045, p=.006$ ) and symbolic threat (standardised $\mathrm{IE}=0.235,95 \% \mathrm{CI}=[0.141,0.326]$, $S E=0.045, p<.001)$ and were statistically significant.

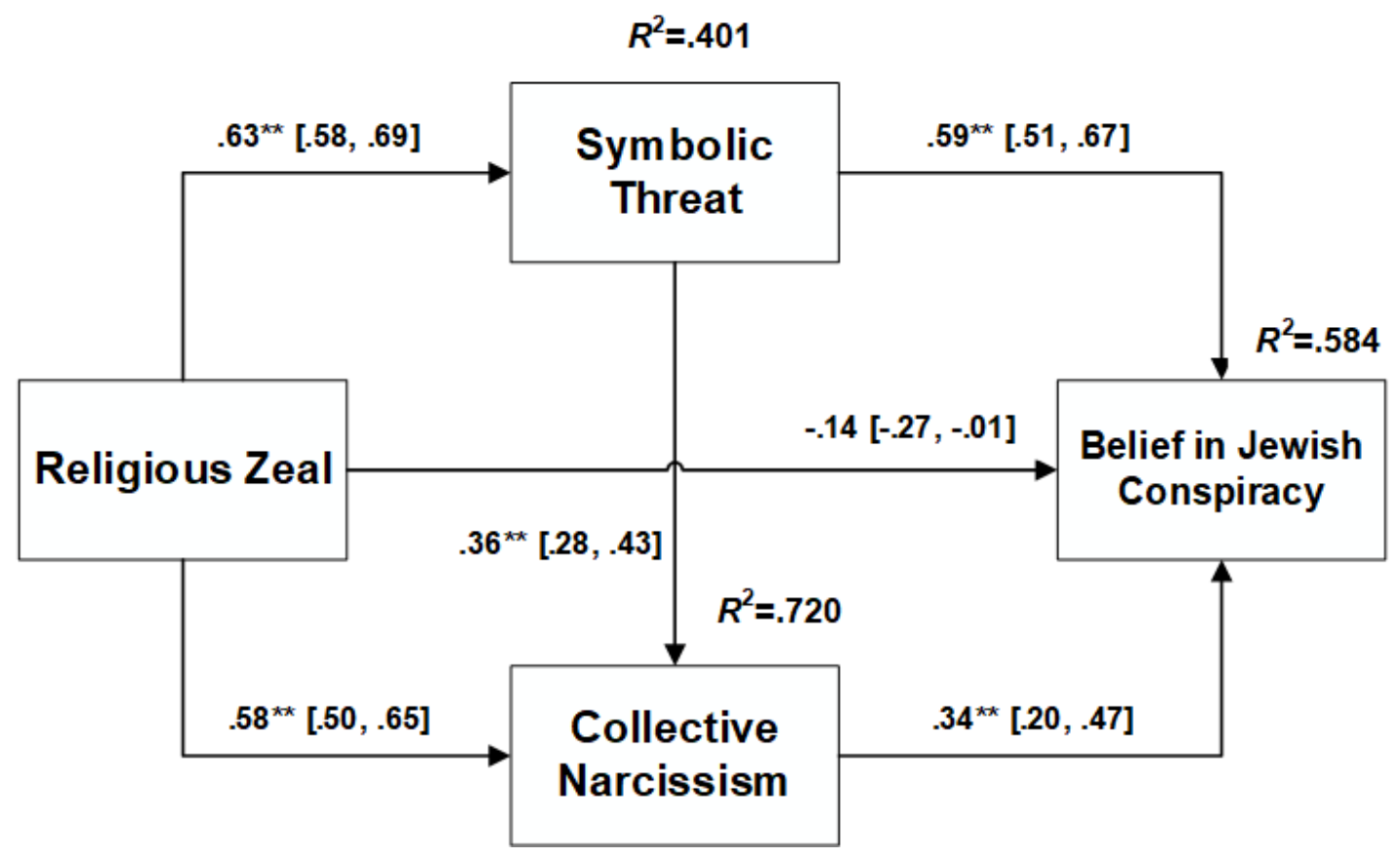

Figure 1. Structural Model of Study 1. $N=385$. Standardised coefficients with $95 \%$ confidence intervals (CIs). Absolute Fit: $\chi^{2}=3304.976, \mathrm{df}=939, p<.000, \mathrm{SRMR}=.073$. Incremental fit: RMSEA $=.073[.070, .076], p$ RMSEA $<.000, \mathrm{CFI}=.978, \mathrm{TLI}=.976, \mathrm{GFI}=.976 .{ }^{*} p<.05,{ }^{* *} p<.001$.

Our study provided strong evidence to support an association between symbolic threat, collective narcissism, and Jewish conspiracy belief, as confirmed by previous research (Cichocka et al., 2016; Mashuri \& Zaduqisti, 2015). We also demonstrated that the salience of religious 
worldviews — represented by religious zeal, predicted stronger support of anti-Semitic conspiracies, but the relationship was fully mediated by symbolic threat and collective narcissism. Simply put, religious zeal activates a sense of outgroup threats, entices delusions of grandeur about their ingroup as a defensive coping mechanism (Golec de Zavala, 2018), and, subsequently, leads to a greater endorsement of Jewish conspiracy belief with the aim to protect the ingroup's positive image. Although we successfully exhibited an underlying mechanism for the emergence of Jewish conspiracy theories, the actual impact of Jewish conspiracy belief still remained unclear.

\section{Study 2}

Study 2 allowed us to expand our questions regarding the interplay between religiosity, belief in a Jewish conspiracy, vaccine conspiracy belief, and vaccination decisions. We predicted that belief in Jewish conspiracies would positively affect vaccine refusal and delay through vaccine conspiracy belief. The mediation would be conditional—participants who believed in Jewish conspiracy theories and declared that religiosity was important in their life would be more likely to endorse vaccine conspiracy theories.

\section{Method}

\section{Participants and Procedure}

Before collecting our sample, we planned our sample size using a Monte Carlo simulation; in order to have the optimal chance (80-90\%) of detecting small-to-medium correlations between the predictors and the outcome variable, we needed to recruit at least 274 
participants. After collecting the data, we managed to enlist 370 Indonesian Muslim parents $\left(M_{\mathrm{age}}=29.14, S D_{\mathrm{age}}=4.66\right.$, age range $=19-47$, females $\left.=78.64 \%\right)$, who, at the time of data collection, had children under 5 years (60 months) of age $\left(M_{\mathrm{age}}=14.48\right.$ months, $S D_{\mathrm{age}}=15.15$ months, age range $=0-60$ months $).$ We circulated the invitation to join the study through social media platforms and instant messaging apps.

After giving their consent to participate, participants were directed to fill out the immunisation behaviour subscale of the Parent Attitudes about Childhood Vaccines (PACV) scale (Opel, Mangione-Smith, et al., 2011; Opel, Taylor, et al., 2011). The subscale was intended to measure participants' decision to delay or refuse vaccinations for their children and for research purposes, we translated the survey into Bahasa Indonesia. We required participants to report their decision by answering six questions, such as, "Have you ever postponed your child getting vaccinated for reasons other than illness or allergies?" and "Overall, how hesitant about childhood shots would you consider yourself to be?" with a range of options. We subsequently scored each question adhering to the scoring guide provided by the scale creator. After carefully conducting a reliability analysis, we decided to drop one item ("It is my role as a parent to question shots") due to its very low item-total correlation coefficient. After dropping an item, the scale reliability was significantly improved $\left(\omega_{t}=.850,95 \% \mathrm{CI}=[.806, .883]\right)$.

Additionally, we asked participants to complete the Belief in Jewish Conspiracy Scale, the same scale we used in Study 1. Reliability estimation yielded a very good reliability coefficient $\left(\omega_{t}=.948,95 \% \mathrm{CI}=[.937, .957]\right)$. Subsequently, participants were asked to complete the translated version of the Vaccine Conspiracy Belief scale (Shapiro et al., 2016). We asked participants to indicate their agreement ( $1=$ strongly disagree, $7=$ strongly agree $)$ with eight items, 
such as, "Pharmaceutical companies cover up the dangers of vaccines" and "The government is trying to cover up the link between vaccines and autism". Reliability analysis revealed a very satisfying coefficient $\left(\omega_{t}=.969,95 \% \mathrm{CI}=[.961, .975]\right)$.

At last, to measure whether religion is a pivotal part of the participants' life, we asked them to fill out the translated version of the Centrality of Religiosity Scale (Huber \& Huber, 2012). Participants indicated their agreement (1-5) with five items, such as, "How often do you experience situations that make you more convinced that God or something divine is involved in your life?" and "How often do you perform compulsory worship? (fasting, five daily prayers, etc.)". After conducting a reliability test, we concluded that the scale was moderately reliable $\left(\omega_{t}=.686,95 \% \mathrm{CI}=[.602, .763]\right)$.

\section{Results and Discussion}

To test our hypothesis, we built a moderated-mediation model by treating all variables in the model as observed variables. Before proceeding to analysis, we summed each item score and entered them into our data analysis (see Table 2 for the descriptive statistics). We also created a two-way interaction term between centrality of religiosity and vaccine conspiracy belief by centering the score of both variables around their mean beforehand. To estimate the model parameters, we used Maximum Likelihood (ML) estimation and bootstrapped model coefficients' standard errors by 1000 iterations. After examining the absolute and incremental fit indices, we concluded that the model was overall a satisfyingly fit (see Figure 2). 
Table 2.

Mean, Standard Deviations of Variables, and Zero-Order Correlations $(N=370)$

\begin{tabular}{cccccc}
\hline Measure & $\boldsymbol{M}(\boldsymbol{S D})$ & $\mathbf{1}$ & $\mathbf{2}$ & $\mathbf{3}$ & $\mathbf{4}$ \\
\hline 1. Vaccine Refusal and Delay & $0.30(0.67)$ & - & & & \\
2. Belief in Jewish Conspiracy & $4.14(1.44)$ & $.236^{* *}$ & - & & \\
3. Vaccine Conspiracy Belief & $2.50(1.53)$ & $.634^{* *}$ & $.495^{* *}$ & - & \\
4. Centrality of Religiosity & $4.14(0.56)$ & .030 & $.221^{* *}$ & .043 & - \\
\hline
\end{tabular}

Note. ${ }^{* *} p<.001$

As seen in Figure 2, belief in Jewish conspiracy had a significant direct effect on

vaccination refusal and delay $(B=-0.018,95 \% \mathrm{CI}=[-0.034,-0.003], S E=0.008, p=.025)$, but the

slope was too small compared to our smallest effect size of interest so it was considered hardly

meaningful. Moreover, participants who showed higher endorsement of Jewish conspiracy

theories were more likely to endorse vaccine conspiracy theories $(B=0.363,95 \% \mathrm{CI}=[0.297$,

0.430], $S E=0.033, p<.001)$. We found no evidence to support an association between centrality of religiosity and vaccine conspiracy beliefs $(B=-0.240,95 \% \mathrm{CI}=[-0.740,0.247], S E=0.215$, $p=.333)$. The interaction effect of centrality of religiosity with belief in Jewish conspiracy to predict vaccine conspiracy beliefs was not significant too $(B=0.009,95 \% \mathrm{CI}=[-0.020,0.036]$, $S E=0.009, p=.540)$. More importantly, participants who believed in vaccine conspiracy theories were more likely to delay or refuse vaccination for their children $(B=0.166,95 \% \mathrm{CI}=[0.138$, 0.192], $S E=0.011, p<.001)$ and, since the direct effect of Jewish conspiracy belief was significant, even after accounting for the effect of vaccine conspiracy beliefs, we calculated the index of moderated mediation (IMM), which resulted in a non-significant IMM (IMM=0.001, $95 \% \mathrm{CI}=[-0.003,0.006], S E=0.002, p=.547)$. 


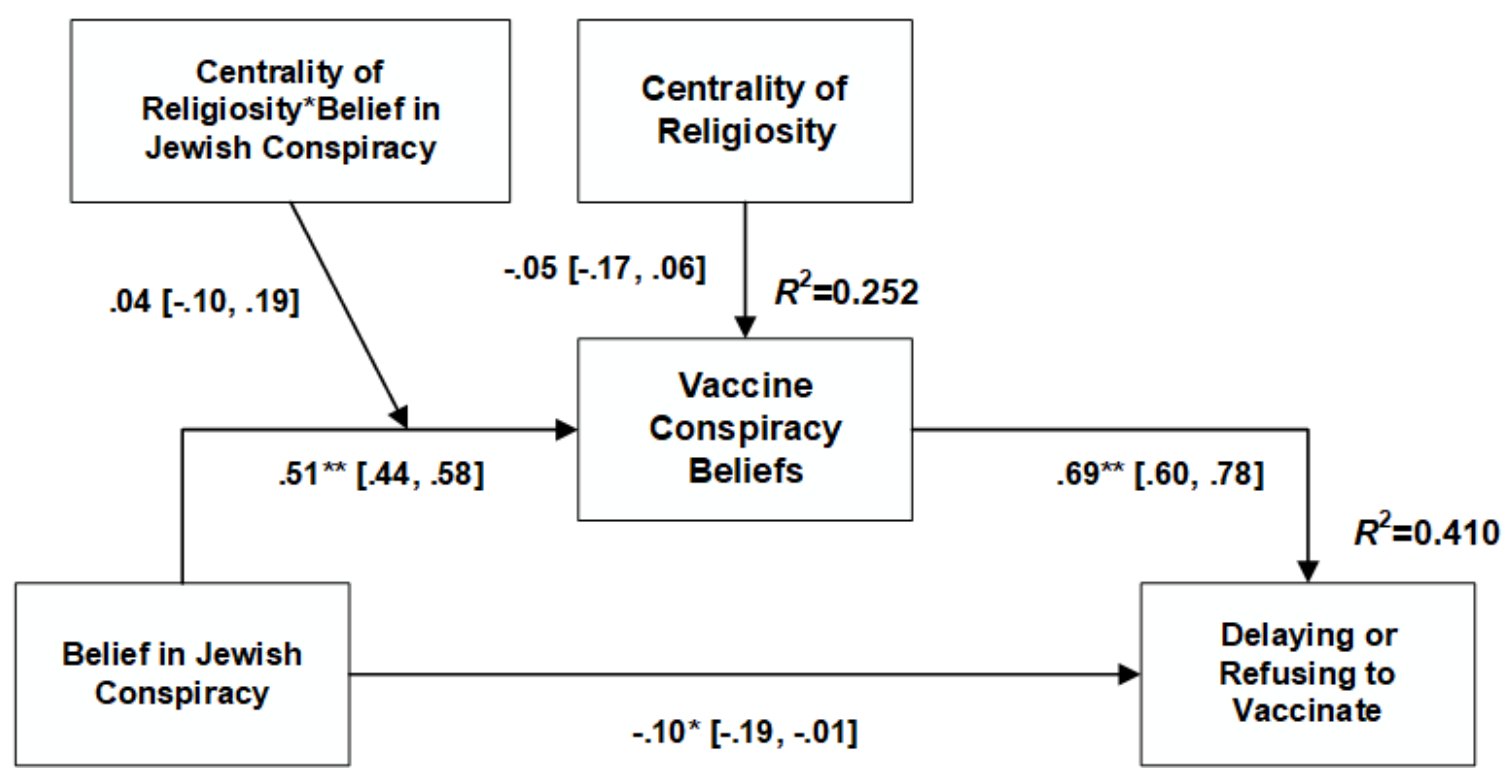

Figure 2. Moderated-Mediation Model of Study 2. $N=370$. Standardised coefficients with 95\% confidence intervals (CIs). Absolute Fit: $\chi^{2}=1.218, \mathrm{df}=2, p=.544$, SRMR $=.009$. Incremental fit: $\mathrm{RMSEA}=.000[.000, .089], p \mathrm{RMSEA}=.769, \mathrm{CFI}=1, \mathrm{TLI}=1, \mathrm{GFI}=.997 .{ }^{*} p<.05,{ }^{*} p<.001$.

In this study, we found that vaccine conspiracy belief mediated the relationship between Jewish conspiracy belief and vaccine refusal and delay. We also detected moderate evidence that belief in vaccine conspiracy theories affected parents' decision to delay or refuse vaccination for their children. In other words, belief in Jewish conspiracy theories indirectly affected vaccination refusal and delay, which diverges from the common assumption that such beliefs are harmless in nature (Ainslie, 2019). Our findings also amplified the notion that conspiracy belief is, in general, dangerous and affects vaccination decisions (Jolley \& Douglas, 2014, 2017). However, we failed to elucidate the role of religiosity in augmenting vaccination refusal and delay. Additionally, our findings were unable to answer the question on why two seemingly unrelated issues, Jewish people and vaccinations, prevailed upon our participants to endorse the senseless belief that vaccination is a product of a malicious conspiracy. 


\section{Study 3}

In Study 3, we intended to map out the conditions under which belief in Jewish conspiracies would lead to stronger confidence in vaccination conspiracy theories. We performed an experimental study predicting that participants whose identity was threatened and exposed, with religious authorities' opposition to the vaccination programme, would be more likely to hold vaccination conspiracy theories. With regard to the coronavirus pandemic, in this study, we also tested our prediction that participants who blamed the pandemic on outgroups, such as the Jews, Chinese Indonesians, and Chinese Nationals would be more likely to refuse a coronavirus vaccination, while those who blamed ingroups, such as their fellow Muslims and Indonesians, would be less likely to do so.

\section{Method}

\section{Participants and Procedure}

In Study 3, we conducted an experimental online study with a 2 (identity threat: yes vs. no) $\times 2$ (religious endorsement for vaccines: endorsed vs. opposed) between-subjects design with belief in Jewish conspiracy as a continuous between-subjects moderator. Before starting to collect data, we planned our sample size using a Monte Carlo simulation. Aiming for 90\% statistical power to detect small-to-medium correlations, we had to recruit at least 368 participants. Our sample consisted of 403 participants, but after excluding those who failed the attention check $(N=7)$, we ended up with 396 individuals (females $=63.38 \%, M_{\text {age }}=27.66$, 
$S D_{\text {age }}=8.67$, age range $\left.=18-58\right)$ who were recruited after seeing an advertisement of our study circulated on various social media platforms and instant messaging apps.

Participants were presented with a detailed information letter and were informed that our study aimed to investigate the interplay between vaccination attitudes and intergroup processes. After providing consent to participate, participants were exposed to three filter questions, which only allowed Muslims, aged 18 years or above and who did not work as a health care worker at the time of data collection, to proceed to the next part of our study. We asked participants to complete the Belief in the Jewish Conspiracy scale, which was used in Study 1 and 2. Reliability analysis resulted in a very good reliability coefficient $\left(\omega_{t}=.961,95 \% \mathrm{CI}=[.954, .967]\right)$. Afterwards, we applied block randomisation, which randomly assigned participants to four different groups (threatening, endorsed; non-threatening, opposed; non-threatening, endorsed; and threatening, opposed) while also balancing gender proportions in each group. To set up the randomisation process, we utilised a random number generator using urns, which is available as a feature on SoSci Survey.

At first, participants were randomly assigned to one of two conditions. In the identity threat condition $(\mathrm{N}=199)$, participants were given a partly-fictional news article about Israeli soldiers attacking the Al-Aqsa Mosque, capturing, and torturing Palestinian Muslim children; in the control condition $(\mathrm{N}=197)$, participants were not provided with the news at all. To perform a manipulation check, we required participants to fill out a symbolic threat questionnaire, which was previously used in Study 1. Reliability analysis yielded a very good reliability coefficient $\left(\omega_{t}=.910,95 \% \mathrm{CI}=[.896, .923]\right)$. 
Afterwards, participants were again randomly selected to one of two conditions. In the religious authorities' endorsement $(N=198)$ condition, participants were provided with a piece of entirely fictional news about cooperation between Bio Farma, Inc., an Indonesian state-owned vaccine company and BiondVax, Inc., from Israel to manufacture coronavirus vaccines, which was facilitated and supported by the Foods, Drugs, and Cosmetics Assessment Institute (Lembaga Pengkajian Pangan, Obat-Obatan, dan Kosmetik-LPPOM) of the Indonesian 'Ulema Council (Majelis 'Ulama Indonesia-MUI). LPPOM MUI is the only authorised body to issue halal certificates in Indonesia-implying that the vaccine would be admissible according to the sharia' law. Meanwhile, in the religious authorities' contention $(N=198)$ condition, participants were given the same article, but with slightly different wording, where the cooperation was instead facilitated by the Indonesian Health Ministry and the LPPOM MUI opposed it since the cooperation would entice controversy among the 'ummah. To check the validity of this manipulation, participants were asked whether they were "hesitant to use the coronavirus vaccine produced by the Israeli company" in the range of 1 (least compatible with my position) to 7 (very compatible with my position) $(M=2.8, S D=2.09)$.

Next, participants were presented with the Vaccine Conspiracy Beliefs scale, which we also used in Study 2. After checking its reliability, we concluded that the scale was reliable $\left(\omega_{t}=.960,95 \% \mathrm{CI}=[.952, .969]\right)$. Also, we asked participants which social groups they tended to blame for the coronavirus outbreak ("When you think about problems caused by coronavirus (COVID-19), which of the following groups do you blame to some extent and should be held responsible for the coronavirus pandemic problem?") on a scale of 1 (very much to be blamed on) to 5 (completely not to be blamed on). We presented the Blame Scale using Kunin 
faces_-negative responses were portrayed by unhappy faces. The social groups were Jews, Indonesian Chinese, Chinese Nationals, Muslims, and Indonesians. The Blame Scale was moderately reliable $\left(\omega_{t}=.816,95 \% \mathrm{CI}=[.781, .847]\right)$.

Participants were subsequently asked to identify their intention to vaccinate themselves ("If a vaccine for coronavirus is available, how likely are you to vaccinate yourself?") and their families ("If a vaccine for coronavirus is available, how likely are you to vaccinate your family?") on a scale of 1 (very much likely to refuse) to 7 (very much likely to accept). Reliability analysis showed a good reliability coefficient $\left(\omega_{t}=.975,95 \% \mathrm{CI}=[.970, .980]\right)$. Finally, we also asked participants how often they directly interacted with Jews on a scale of 1 (never at all) to 4 (almost every day).

After completing all parts of the study, participants were fully debriefed, thanked, and offered a chance to enter a prize draw. Participants were fully informed about the fictitious nature of the news article and we also provided factual information about coronavirus vaccines. We are very sure that our debriefing worked as intended since the cooperation between Bio Farma, Inc and BiondVax, Inc never happened before and a few weeks after our data collections, in mid July, Bio Farma, Inc announced that they are working closely with Sinovac Biotech to carry out the phase 3 clinical trial study (Sutrisno, 2020).

\section{Results and Discussion}

Manipulation Check. To test the validity of the identity threat manipulation, a $t$-test for independent groups (Patil, 2018) was conducted with the identity threat condition as an independent variable and symbolic threat as a dependent variable. The manipulation check 
failed, even though participants' symbolic threat perception was slightly higher in the threatening condition $(M=3.28, S D=1.47)$ than in the non-threatening condition $(M=3.03$, $S D=1.68), t(386.32)=-1.58, p=.114$, Hedges' $g=-0.16,95 \% \mathrm{CI}=[-0.36,0.04]$. In support of the religious authorities endorsement, participants were slightly less hesitant to take vaccination when it was endorsed by religious authorities $(M=2.63, S D=1.99)$ rather than when it was opposed $(M=3.08, S D=2.02), t(393.92)=2.26, p=.025$, Hedges' $g=0.23,95 \% \mathrm{CI}=[0.03,0.42]$. Descriptive statistics and zero-order correlations for the variables of interest are provided in Table 3.

Table 3.

Mean, Standard Deviations of Variables, and Zero-Order Correlations $(N=396)$

\begin{tabular}{lccccc}
\multicolumn{1}{c}{ Measure } & $\boldsymbol{M}(\boldsymbol{S D})$ & $\mathbf{1}$ & $\mathbf{2}$ & $\mathbf{3}$ & $\mathbf{4}$ \\
\hline 1. Vaccine Conspiracy Belief & $2.45(1.62)$ & - & & \\
$\begin{array}{l}\text { 2. Belief in Jewish } \\
\text { Conspiracy }\end{array}$ & $3.55(1.67)$ & .709 & - & \\
3. Blame & $3.34(0.88)$ & -.348 & -.404 & - \\
4. Vaccination Intention & $2.50(1.75)$ & -.572 & -.398 & .249 & - \\
\hline
\end{tabular}

Note. $\mathrm{VCB}=$ Vaccine Conspiracy Belief; BJC = Belief in Jewish Conspiracy; BL = Blame; $\mathrm{VI}=$ Vaccination Intention. All correlations are significant at $p<.001$ level. 
Randomisation Check. To test the success of our block randomisation procedure, we performed a 2 (identity threat: yes vs. no) $\times 2$ (religious endorsement for vaccines: endorsed vs. opposed) ANOVA with belief in Jewish conspiracy as a dependent variable. Our analysis showed that belief in Jewish conspiracy was equally distributed between the threatening $(M=3.54$, $S D=1.61)$ and non-threatening condition $(M=3.56, S D=1.73), F(1,392)=0.021, p=.886$, $\eta^{2}=0.00005,95 \%$ CI $\left.[0.00,0.01]\right)$, and between endorsement $(M=3.42, S D=1.65)$ and contentment $(M=3.68, S D=1.69)$ condition, $F(1,392)=2.358, p=.125, \eta^{2}=0.005,95 \% \mathrm{CI}[0.00$, 0.03]). There was no evidence to confirm an interaction between both conditions $F(1$, $392)=0.376, p=.540, \eta^{2}=0.0009,95 \%$ CI $\left.[0.00,0.02]\right)$.

Vaccine Conspiracy Belief. We expected that participants whose identity was threatened and who were presented with contention against a vaccine from religious authorities would be more likely to believe vaccine conspiracy theories compared to those whose identity was not threatened and who were presented with a vaccine endorsement from religious authorities. To test our hypothesis, we performed a moderated regression analysis with vaccine conspiracy belief as a dependent variable and belief in Jewish conspiracy as a between-subject covariate. We also tested two-way interactions between belief in Jewish conspiracy with identity threat, belief in Jewish conspiracy with religious authorities endorsement, and identity threat with religious authorities endorsement. Belief in Jewish conspiracy was centred around its mean prior to analysis. Identity threat $(-1=$ control, $1=$ threatening $)$ and religious authorities endorsement $(-1=$ opposed, $1=$ endorsed) were effect-coded (Kugler et al., 2018).

In sum, our model showed a good fit $\left(F(6,389)=66.46, p<.001, R^{2}=.506\right)$ accounting for $50.6 \%$ of the variance of vaccine conspiracy beliefs. We checked model diagnostics, including 
homoscedasticity, residual normality, multicollinearity, and Cook's distance and the model did not violate any assumptions of linear regression. Our result showed that only belief in Jewish conspiracy $(B=0.455,95 \% \mathrm{CI}=[0.409,0.5], S E=0.023, t=19.671, p<.001)$ significantly predicted vaccine conspiracy belief. We did not find compelling evidence to conclude any significant effects of identity threat $(B=0.239,95 \% \mathrm{CI}=[-0.667,1.145], S E=0.461, t=0.519, p=.604)$, religious endorsement $(B=-0.364,95 \% \mathrm{CI}=[-1.274,0.544], S E=0.462, t=-0.789, p=.431)$, or two-way interactions between belief in Jewish conspiracy with identity threat $(B=-0.012,95 \%$ $\mathrm{CI}=[-0.057,0.033], S E=0.023, t=-0.535, p=.593)$, belief in Jewish conspiracy with religious authorities' endorsement $(B=-0.020,95 \% \mathrm{CI}=[-0.065,0.024], S E=0.023, t=-0.885, p=.377)$, and identity threat with religious authorities endorsement $(B=0.243,95 \% \mathrm{CI}=[-0.666,1.152]$, $S E=0.462, t=0.526, p=.599)$ when predicting vaccine conspiracy belief.

Coronavirus Vaccination Intention. We hypothesised that participants who blamed the pandemic on outgroups (Jews, Chinese Indonesians, and Chinese Nationals) would be more likely to refuse a coronavirus vaccination when it becomes available, while those who blamed ingroups (Muslims and Indonesians) for the outbreak would be less likely to do so. In order to test this hypothesis, we conducted a multiple linear regression analysis with vaccination intention as a dependent variable and blame (on Jews, Chinese Indonesians, Chinese Nationals, Muslims, and Indonesians) as dependent variables. In general, our model was a good fit $(F(5,390)=17.42$, $p<.001, R^{2}=.182$ ) and accounted for $18.2 \%$ of the variance of coronavirus vaccination intention. We also examined model diagnostics, including homoscedasticity, multicollinearity, residual normality, and Cook's distance and the model did not violate any assumptions of linear regression. 
As expected, our analysis showed that participants who blamed the Jews $(B=1.102,95 \%$ $\mathrm{CI}=[0.760,1.444], S E=0.174, t=6.332, p<.001)$ for the coronavirus pandemic would be more likely to refuse a vaccination when available. The result was interesting because the majority of our participants $(66.67 \%)$ reported that they never directly interacted with Jews, while only $2.52 \%$ reported that they interacted with Jews almost daily, $19.19 \%$ said several times, and $11.61 \%$ declared only once. Conversely, participants who blamed their fellow Muslims $(B=-0.439,95 \% \mathrm{CI}=[-0.852,-0.027], S E=0.209, t=-2.095, p=.036)$ were less likely to intend to refuse vaccination.

More interestingly, we did not find evidence to confirm that blaming Chinese Indonesians $(B=0.216,95 \% \mathrm{CI}=[-0.158,0.591], S E=0.190, t=1.133, p=.257)$, Chinese Nationals $(B=0.181$, $95 \% \mathrm{CI}=[-0.141,0.505], S E=0.164, t=1.108, p=.268)$, or fellow Indonesians $(B=-0.312,95 \%$ $\mathrm{CI}=[-0.671,0.046], S E=0.182, t=-1.712, p=.087)$ affected participants' coronavirus vaccination intention.

Discussion. We replicated our findings in Study 2 that belief in a Jewish conspiracy was strongly associated with vaccine conspiracy beliefs. In stark contrast to our hypothesis, our analysis did not yield any substantial evidence to support the effect of both identity threat and religious authorities' endorsement of vaccination on conspiracy belief about the vaccine. Although previous research demonstrated that conspiracy belief is particularly stronger when group identity is under attack (Jolley et al., 2018; Mashuri \& Zaduqisti, 2015), our research did not provide any support for the hypothesis that those who upheld Jewish conspiracy theory whose identity was under attack would be more likely to have a stronger belief in vaccine conspiracy theories. We also initially suspected that religious authorities' endorsement to 
vaccination would attenuate the correlation between Jewish and vaccine conspiracy belief, but again, we failed to find any evidence to support this hypothesis. In sum, although sheer evidence suggests that religious incompatibility is a prominent factor in vaccine hesitancy (Dubé, Gagnon, et al., 2014; Larson et al., 2016), we reckon that its underlying cause is much more complex than what is seen on the surface since religious conspiracy theorists would not easily give up their illogical views even after being countered by religious authorities.

During a crisis, the tension between social groups is intensified as group members are extremely motivated to make sense of the crisis while at the same time protecting their ingroup's reputation. As for the coronavirus pandemic, the crisis activates the "othering" hypothesis that subsequently leads to intensified xenophobic attitudes towards certain social groups as it becomes central in the rhetoric of the elites (Reny \& Barreto, 2020). For example, studies in the US demonstrated that the upsurge of prejudice towards Asians during coronavirus outbreaks has been staggering (Croucher et al., 2020; Reny \& Barreto, 2020) while blaming the Jews for the pandemic is unsurprisingly common among Islamists in Turkey and Iran as well as white supremacists in West Europe (Topor, 2020). Despite the prevalence of such beliefs, there is scarce evidence to confirm the conjecture on how these derogatory attitudes would affect the effort to curb the infections. In our study, we uncannily observed evidence that blaming an almost non-existent group could prevail upon our participants to potentially refuse vaccination, even though so far, vaccination is admitted as one of the most effective strategies to eradicate the disease. Put simply, we reject the purportedly benign nature of the anti-Jewish rhetoric since it is neither benign nor negligible. 


\section{General Discussion}

Jewish conspiracy theories are a popular belief in Southeast Asia, especially in Indonesia and neighbouring Malaysia, albeit the fact that Jewish population is minuscule and almost invisible religious minorities in the region. Despite the assertion that conspiracy belief against Jews is a rather trivial phenomenon (Ainslie, 2019), our research has demonstrated otherwise. Jewish conspiracy theories are not benign and could convey real-life consequences, such as anti-Sino racism (Swami, 2012) and vaccination decisions (Study 3). Our study showed that conspiracy belief about Jews was associated with a stronger belief in vaccine conspiracy (Study 2 and 3 ) and could indirectly affect vaccination refusal and delay (Study 2) so that it refutes the premise of the harmlessness of Jewish conspiracy belief. The danger of anti-Semitism rhetoric was also reflected in Study 3 where participants who blamed Jews for the coronavirus pandemic would be more likely to refuse a vaccination for themselves and their families if the vaccine is ever available. It is, however, still unclear how and when our participants equated the idea of anti-Semitism with vaccination.

Our suspicion lies in the deeply held views about Jews among Muslims that perceives them as cunningly intelligent, but lacking moral qualities (Reid, 2010). It is then not surprising that the Islamists carelessly correspond a morally-contentious product of advanced technology, such as vaccines, with Jewish conspiracy. According to the Stereotype Content Model (Cuddy et al., 2008, 2009), our perception of outgroups is generally determined by two factors; perceived competence and warmth. It is possible that Indonesian Muslims perceive Jews as highly competent, but lacking warmth (Fiske, 2018), quite similar to how Poles see Jews (Bilewicz, 
Michał \& Krzeminski, 2010)_-inducing group deprivation subsequently leads to the suspicions that Jews are conspiring against Muslims (Biddlestone et al., 2020). However, further research is needed to shed light on this conjecture.

Past research suggests that conspiracy beliefs prevail when an ingroup's image is seriously attacked (Cichocka et al., 2016; Jolley et al., 2018; Mashuri \& Zaduqisti, 2015), but we only observed partial evidence to support this premise. First, our findings indeed confirmed that symbolic threat played an important role to explain why religious individuals are more likely to put their faith in Jewish conspiracy theories (Study 1). However, we failed to observe evidence that identity threat would bolster the connection between Jewish and vaccine conspiracy (Study 3). Our findings could signify the pervasiveness of Jewish conspiracy theories among Indonesian Muslims and its plausibility to serve its function as ideological underpinnings. We also failed to witness the effect of religious authorities' endorsement of a vaccine on debilitating the association between Jewish conspiracy belief and vaccination conspiracy belief (Study 3). Endorsement from clerics did not easily change participants' conspiracist ideation, while typically in Indonesia, “even liberal suspicion need not undermine Islamic authorities” (Long, 2017 , p. 713). This indicates that the emergence of vaccine conspiracy belief in a religious community, such as in Indonesia, might not be caused by a mere religious disputation about vaccines.

We did not find any substantial evidence to support the role of religious centrality in reinforcing the association between Jewish conspiracy and vaccination conspiracy belief (Study 2) and finding that religious zeal only indirectly affected Jewish conspiracy belief (Study 1). Although the dialogue between science and religion has been seemingly contentious and several 
pieces of evidence set in the positive association between religiosity and endorsement of anti-science narratives (McPhetres \& Zuckerman, 2018; Rutjens et al., 2018), including conspiracy belief (Jasinskaja-Lahti \& Jetten, 2019), our research suggested that this connection is somewhat spurious. In a predominantly religious community, such as in Indonesia, it is more likely that intergroup aspects trump religious worldviews in championing conspiracy beliefs.

The major limitation of our studies is that due to the resources constraint, we could not afford to draw a nationally representative sample. It is possible that our sampling variability might be higher than we desired and our conclusions, therefore, should be interpreted with some cautions, especially concerning the question on the generalisability of the findings. In a similar vein, we strongly encourage other researchers to further gather stronger evidence by conducting, for example, replication research. Nonetheless, our research has raised important questions regarding the nature and societal implications of Jewish conspiracy theories among Indonesian Muslims where empirical findings on this topic are still largely left in a dark spot. 


\section{References}

Ainslie, M. J. (2019). Anti-Semitism in Contemporary Malaysia: Malay Nationalism, Philosemitism and Pro-Israel Expressions. Springer Singapore. https://doi.org/10.1007/978-981-13-6013-8

Ali, M. (2010). 'THEY ARE NOT ALL ALIKE': Indonesian Muslim intellectuals' perception of Judaism and Jews. Indonesia and the Malay World, 38(112), 329-347. https://doi.org/10.1080/13639811.2010.513845

Beaujean, A. A. (2014). Sample Size Determination for Regression Models Using Monte Carlo Methods in R. Practical Assessment, Research \& Evaluation, 19(12). https://doi.org/10.7275/d5pv-8v28

Biddlestone, M., Cichocka, A., Žeželj, I., \& Bilewicz, M. (2020). Conspiracy Theories and Intergroup Relations (pp. 219-230). Routledge.

Bilewicz, Michał, \& Krzeminski, I. (2010). Anti-Semitism in Poland and Ukraine: The Belief in Jewish Control as a Mechanism of Scapegoating. International Journal of Conflict and Violence, 4(2), 234-243.

Cichocka, A. (2016). Understanding defensive and secure in-group positivity: The role of collective narcissism. European Review of Social Psychology, 27(1), 283-317. https://doi.org/10.1080/10463283.2016.1252530

Cichocka, A., Golec de Zavala, A., Marchlewska, M., \& Olechowski, M. (2015). Grandiose Delusion: Collective narcissism, secure in-group identification, and belief in conspiracies. In M. Bilewicz, A. Cichocka, \& W. Soral (Eds.), The Psychology of Conspiracy (pp. 42-67). Routledge. 
Cichocka, A., Marchlewska, M., \& Golec de Zavala, A. (2016). Does Self-Love or Self-Hate Predict Conspiracy Beliefs? Narcissism, Self-Esteem, and the Endorsement of Conspiracy Theories. Social Psychological and Personality Science, 7(2), 157-166. https://doi.org/10.1177/1948550615616170

Croucher, S. M., Nguyen, T., \& Rahmani, D. (2020). Prejudice Toward Asian Americans in the Covid-19 Pandemic: The Effects of Social Media Use in the United States. Frontiers in Communication, 5. https://doi.org/10.3389/fcomm.2020.00039

Cuddy, A. J. C., Fiske, S. T., \& Glick, P. (2008). Warmth and Competence as Universal Dimensions of Social Perception: The Stereotype Content Model and the BIAS Map. In Advances in Experimental Social Psychology (Vol. 40, pp. 61-149). Elsevier. https://doi.org/10.1016/S0065-2601(07)00002-0

Cuddy, A. J. C., Fiske, S. T., Kwan, V. S. Y., Glick, P., Demoulin, S., Leyens, J.-P., Bond, M. H., Croizet, J.-C., Ellemers, N., Sleebos, E., Htun, T. T., Kim, H.-J., Maio, G., Perry, J., Petkova, K., Todorov, V., Rodríguez-Bailón, R., Morales, E., Moya, M., ... Ziegler, R. (2009). Stereotype content model across cultures: Towards universal similarities and some differences. British Journal of Social Psychology, 48(1), 1-33. https://doi.org/10.1348/014466608X314935

Darwin, H., Neave, N., \& Holmes, J. (2011). Belief in conspiracy theories. The role of paranormal belief, paranoid ideation and schizotypy. Personality and Individual Differences, 50(8), 1289-1293. https://doi.org/10.1016/j.paid.2011.02.027

Douglas, K. M., Uscinski, J. E., Sutton, R. M., Cichocka, A., Nefes, T., Ang, C. S., \& Deravi, F. (2019). Understanding Conspiracy Theories. Political Psychology, 40(S1), 3-35. 
https://doi.org/10.1111/pops. 12568

Dubé, E., Gagnon, D., Nickels, E., Jeram, S., \& Schuster, M. (2014). Mapping vaccine hesitancy-Country-specific characteristics of a global phenomenon. Vaccine, 32(49), 6649-6654. https://doi.org/10.1016/j.vaccine.2014.09.039

Dubé, E., Vivion, M., \& MacDonald, N. E. (2014). Vaccine hesitancy, vaccine refusal and the anti-vaccine movement: Influence, impact and implications. Expert Review of Vaccines, 14(1), 99-117. https://doi.org/10.1586/14760584.2015.964212

Dunn, T. J., Baguley, T., \& Brunsden, V. (2014). From alpha to omega: A practical solution to the pervasive problem of internal consistency estimation. British Journal of Psychology, 105(3), 399-412. https://doi.org/10.1111/bjop.12046

Franke, E. (2013). Searching for Traces of Judaism in Indonesia. In M. Hutter \& U. Vollmer (Eds.), Between Mumbai and Manila: Judaism in Asia since the Founding of the State of Israel. Bonn University Press.

Franks, B., Bangerter, A., \& Bauer, M. W. (2013). Conspiracy theories as quasi-religious mentality: An integrated account from cognitive science, social representations theory, and frame theory. Frontiers in Psychology, 4. https://doi.org/10.3389/fpsyg.2013.00424

Golec de Zavala, A. (2011). Collective Narcissism and Intergroup Hostility: The Dark Side of 'In-Group Love' Social and Personality Psychology Compass, 5(6), 309-320. https://doi.org/10.1111/j.1751-9004.2011.00351.x

Golec de Zavala, A., \& Cichocka, A. (2012). Collective narcissism and anti-Semitism in Poland. Group Processes and Intergroup Relations, 15(2), 213-229. https://doi.org/10.1177/1368430211420891 
Golec de Zavala, A., Cichocka, A., Eidelson, R., \& Jayawickreme, N. (2009). Collective narcissism and its social consequences. Journal of Personality and Social Psychology, 97(6), 1074-1096. https://doi.org/10.1037/a0016904

Golec de Zavala, A., \& Federico, C. M. (2018). Collective narcissism and the growth of conspiracy thinking over the course of the 2016 United States presidential election: A longitudinal analysis. European Journal of Social Psychology, 48(7), 1011-1018. https://doi.org/10.1002/ejsp.2496

Golec de Zavala, A., Guerra, R., \& Simão, C. (2017). The relationship between the Brexit vote and individual predictors of prejudice: Collective narcissism, right-wing authoritarianism, social dominance orientation. Frontiers in Psychology, 8(NOV), 1-14. https://doi.org/10.1161/CIRCRESAHA.116.302795

Golec de Zavala, A., Peker, M., Guerra, R., \& Baran, T. (2016). Collective Narcissism Predicts Hypersensitivity to In-group Insult and Direct and Indirect Retaliatory Intergroup Hostility: Collective narcissism and hypersensitivity to in-group image insult. European Journal of Personality, 30(6), 532-551. https://doi.org/10.1002/per.2067

Hadler, J. (2004). Translations of antisemitism: Jews, the Chinese, and violence in colonial and post-colonial Indonesia. Indonesia and the Malay World, 32(94), 291-313. https://doi.org/10.1080/13639810500031012

Heriyanto, D. (2018). Indonesian youths say religion key to happiness, bucking Global trend. The Jakarta Post. https://www.thejakartapost.com/news/2018/06/01/indonesian-youths-say-religion-key-tohappiness-bucking-global-trend.html 
Huber, S., \& Huber, O. W. (2012). The Centrality of Religiosity Scale (CRS). Religions, 3(3), 710-724. https://doi.org/10.3390/rel3030710

Imhoff, R., \& Lamberty, P. K. (2017). Too special to be duped: Need for uniqueness motivates conspiracy beliefs: Need for uniqueness and conspiracies. European Journal of Social Psychology, 47(6), 724-734. https://doi.org/10.1002/ejsp.2265

Jasinskaja-Lahti, I., \& Jetten, J. (2019). Unpacking the relationship between religiosity and conspiracy beliefs in Australia. The British Journal of Social Psychology, 58(4), 938-954. https://doi.org/10.1111/bjso.12314

Jolley, D., \& Douglas, K. M. (2014). The effects of anti-vaccine conspiracy theories on vaccination intentions. PLoS ONE, 9(2). https://doi.org/10.1371/journal.pone.0089177

Jolley, D., \& Douglas, K. M. (2017). Prevention is better than cure: Addressing anti-vaccine conspiracy theories. Journal of Applied Social Psychology, 47(8), 459-469. https://doi.org/10.1111/jasp.12453

Jolley, D., Douglas, K. M., \& Sutton, R. M. (2018). Blaming a Few Bad Apples to Save a Threatened Barrel: The System-Justifying Function of Conspiracy Theories: System-Justifying Function of Conspiracy Theories. Political Psychology, 39(2), 465-478. https://doi.org/10.1111/pops.12404

Jolley, D., Meleady, R., \& Douglas, K. M. (2019). Exposure to intergroup conspiracy theories promotes prejudice which spreads across groups. British Journal of Psychology. https://doi.org/10.1111/bjop.12385

Jolley, D., \& Paterson, J. L. (2020). Pylons ablaze: Examining the role of 5G COVID-19 conspiracy beliefs and support for violence. British Journal of Social Psychology, 59(3), 
628-640. https://doi.org/10.1111/bjso.12394

Kelley, K. (2018). MBESS: The MBESS R Package (R package version 4.4.3) [Computer software]. https://CRAN.R-project.org/package=MBESS

Kelley, K., \& Pornprasertmanit, S. (2016). Confidence intervals for population reliability coefficients: Evaluation of methods, recommendations, and software for composite measures. Psychological Methods, 21(1), 69-92. https://doi.org/10.1037/a0040086

Kofta, M., Soral, W., \& Bilewicz, M. (2020). What breeds conspiracy antisemitism? The role of political uncontrollability and uncertainty in the belief in Jewish conspiracy. Journal of Personality and Social Psychology. https://doi.org/10.1037/pspa0000183

Krekó, P. (2015). Conspiracy theory as collective motivated cognition. In M. Bilewicz, A. Cichocka, \& W. Soral (Eds.), The Psychology of Conspiracy (pp. 63-78). Routledge.

Kugler, K. C., Dziak, J. J., \& Trail, J. (2018). Coding and Interpretation of Effects in Analysis of Data from a Factorial Experiment. In L. M. Collins \& K. C. Kugler (Eds.), Optimization of Behavioral, Biobehavioral, and Biomedical Interventions: Advanced Topics (pp. 175-205). Springer International Publishing. https://doi.org/10.1007/978-3-319-91776-4_6

Larson, H. J., de Figueiredo, A., Xiahong, Z., Schulz, W. S., Verger, P., Johnston, I. G., Cook, A. R., \& Jones, N. S. (2016). The State of Vaccine Confidence 2016: Global Insights Through a 67-Country Survey. EBioMedicine, 12, 295-301. https://doi.org/10.1016/j.ebiom.2016.08.042

Lewandowsky, S., Oberauer, K., \& Gignac, G. E. (2013). NASA Faked the Moon Landing--Therefore, (Climate) Science Is a Hoax: An Anatomy of the Motivated 
Rejection of Science. Psychological Science, 24(5), 622-633.

https://doi.org/10.1177/0956797612457686

Li, C.-H. (2016). The performance of ML, DWLS, and ULS estimation with robust corrections in structural equation models with ordinal variables. Psychological Methods, 21(3), 369-387. https://doi.org/10.1037/met0000093

Long, N. J. (2017). On the Islamic authority of the Indonesian state: Responsibility, suspicion, and acts of compliance. Journal of the Royal Anthropological Institute, 23(4), 709-726. https://doi.org/10.1111/1467-9655.12698

Marchlewska, M., Cichocka, A., Łozowski, F., Górska, P., \& Winiewski, M. (2019). In search of an imaginary enemy: Catholic collective narcissism and the endorsement of gender conspiracy beliefs. The Journal of Social Psychology, 1-14.

https://doi.org/10.1080/00224545.2019.1586637

Mashuri, A., \& Zaduqisti, E. (2015). The Effect of Intergroup Threat and Social Identity Salience on the Belief in Conspiracy Theories over Terrorism in Indonesia: Collective Angst as a Mediator. International Journal of Psychological Research, 8(1), 24-35.

Mashuri, A., \& Zaduqisti, E. (2019). Explaining Muslims’ Aggressive Tendencies Towards the West: The Role of Negative Stereotypes, Anger, Perceived Conflict and Islamic Fundamentalism. Psychology and Developing Societies, 31(1), 56-87. https://doi.org/10.1177/0971333618819151

McGregor, I., Prentice, M., \& Nash, K. (2013). Anxious Uncertainty and Reactive Approach Motivation (RAM) for Religious, Idealistic, and Lifestyle Extremes. Journal of Social Issues, 69(3), 537-563. https://doi.org/10.1111/josi.12028 
McPhetres, J., \& Zuckerman, M. (2018). Religiosity predicts negative attitudes towards science and lower levels of science literacy. PLOS ONE, 13(11), e0207125. https://doi.org/10.1371/journal.pone.0207125

Nyhan, B., \& Zeitzoff, T. (2018). Conspiracy and Misperception Belief in the Middle East and North Africa. The Journal of Politics, 80(4), 1400-1404. https://doi.org/10.1086/698663

Opel, D. J., Mangione-Smith, R., Taylor, J. A., Korfiatis, C., Wiese, C., Catz, S., \& Martin, D. P. (2011). Development of a survey to identify vaccine-hesitant parents: The parent attitudes about childhood vaccines survey. Human Vaccines, 7(4), 419-425. https://doi.org/10.4161/hv.7.4.14120

Opel, D. J., Taylor, J. A., Mangione-Smith, R., Solomon, C., Zhao, C., Catz, S., \& Martin, D. (2011). Validity and reliability of a survey to identify vaccine-hesitant parents. Vaccine, 29(38), 6598-6605. https://doi.org/10.1016/j.vaccine.2011.06.115

Patil, I. (2018). ggstatsplot: “ggplot2” Based Plots with Statistical Details [R; CRAN]. https://cran.r-project.org/web/packages/ggstatsplot/index.html

Pornprasertmanit, S., Miller, P., Schoemann, A., Jorgensen, T. D., \& Quick, C. (2020). simsem: SIMulated Structural Equation Modeling (0.5-15) [R; CRAN]. https://cran.r-project.org/web/packages/simsem/index.html

R Core Team. (2019). R: A Language and Environment for Statistical Computing. R Foundation for Statistical Computing. https://www.R-project.org/

Reid, A. (2010). Jewish-Conspiracy Theories in Southeast Asia: Are Chinese the target? Indonesia and the Malay World, 38(112), 373-385. https://doi.org/10.1080/13639811.2010.513848 
Reny, T. T., \& Barreto, M. A. (2020). Xenophobia in the time of pandemic: Othering, anti-Asian attitudes, and COVID-19. Politics, Groups, and Identities, 0(0), 1-24. https://doi.org/10.1080/21565503.2020.1769693

Riyanto, G. (2018). Histeria Anti-Vaksin: Agamawan Menyemai, Ilmuwan Memulai ["Anti-Vaccine Hysteria: Clerics sow, scientists begin"]. tirto.id. https://tirto.id/histeria-anti-vaksin-agamawan-menyemai-ilmuwan-memulai-cQRG

Rutjens, B. T., Heine, S. J., Sutton, R. M., \& van Harreveld, F. (2018). Attitudes Towards Science. In Advances in Experimental Social Psychology (Vol. 57, pp. 125-165). Elsevier. https://doi.org/10.1016/bs.aesp.2017.08.001

Saputra, R. R. (2020). Muhammadiyah Sesalkan Isu Corona Konspirasi Yahudi dan China ["Muhammadiyah regrets the issue of Corona, Jewish and Chinese Conspiracy"]. CNN Indonesia. https://www.cnnindonesia.com/nasional/20200427162024-20-497724/muhammadiyah-se salkan-isu-corona-konspirasi-yahudi-dan-china

Shapiro, G. K., Holding, A., Perez, S., Amsel, R., \& Rosberger, Z. (2016). Validation of the vaccine conspiracy beliefs scale. Papillomavirus Research, 2, 167-172. https://doi.org/10.1016/j.pvr.2016.09.001

Siegel, J. T. (2000). Kiblat and the Mediatic Jew. Indonesia, 69, 9-40. JSTOR. https://doi.org/10.2307/3351275

Sitohang, V. (2019, February 11). Kebijakan Penyelenggaraan Imunisasi ["The Immunisation Policy"]. Rapat Kerja Kesehatan Nasional (Rakerkesnas) 2019, Jakarta. https://www.kemkes.go.id/resources/download/info-terkini/rakerkesnas-2019/SESI\%20I/ 
Kelompok\%205/4-Kebijakan-Penyelenggaraan-Imunisasi.pptx

Stephan, W. G., \& Stephan, C. W. (2000). An integrated threat theory of prejudice. In S. Oskamp (Ed.), Reducing Prejudice and Discrimination (pp. 23-45). Lawrence Erlbaum Associates.

Stephan, W. G., \& Stephan, C. W. (2017). Intergroup Threat Theory. In Y. Y. Kim (Ed.), The International Encyclopedia of Intercultural Communication (Vol. 2). John Wiley \& Sons, Inc. https://doi.org/10.1002/9781118783665

Swami, V. (2012). Social Psychological Origins of Conspiracy Theories: The Case of the Jewish Conspiracy Theory in Malaysia. Frontiers in Psychology, 3, 280. https://doi.org/10.3389/fpsyg.2012.00280

Swami, V., Barron, D., Weis, L., \& Furnham, A. (2018). To Brexit or not to Brexit: The roles of Islamophobia, conspiracist beliefs, and integrated threat in voting intentions for the United Kingdom European Union membership referendum. British Journal of Psychology, 109(1), 156-179. https://doi.org/10.1111/bjop.12252

Topor, L. (2020). COVID-19: Blaming the Jews for the Plague, Again. Fathom Journal. https://fathomjournal.org/covid-19-blaming-the-jews-for-the-plague-again/ van Bruinessen, M. (1994). Yahudi sebagai Simbol dalam Wacana Islam Indonesia Masa Kini ["The Jew as a symbol in contemporary Muslim discourse in Indonesia"]. In Spiritualitas baru: Agama dan aspirasi rakyat (pp. 253-268). Dian/Interfidei.

https://dspace.library.uu.nl/handle/1874/20532

van Bruinessen, M. (2002). Genealogies of Islamic Radicalism in Post-Suharto Indonesia. South East Asia Research, 10(2), 117-154. https://doi.org/10.5367/000000002101297035 
van Prooijen, J.-W., \& Douglas, K. M. (2017). Conspiracy theories as part of history: The role of societal crisis situations. Memory Studies, 10(3), 323-333.

https://doi.org/10.1177/1750698017701615

van Prooijen, J.-W., Staman, J., \& Krouwel, A. P. M. (2018). Increased conspiracy beliefs among ethnic and Muslim minorities. Applied Cognitive Psychology, 32(5), 661-667. https://doi.org/10.1002/acp.3442

Yves, R. (2012). lavaan: An R package for structural equation modelling. Journal of Statistical Software, 48(2), 1-36. 